\title{
Upaya Menekan Perilaku Mematuk Bulu yang Memicu Perilaku Kanibalisme pada Peternakan Ayam
}

\section{The Efforts to Decrease Feather Pecking Behavior that Trigger Cannibalism Behavior in Chicken Farms}

\author{
C. Hidayat* \\ Balai Penelitian Ternak, PO Box 221, Bogor - 16720, Indonesia \\ *E-mail: hidayat_c2p@yahoo.com \\ (Diterima: 06 April 2019; Disetujui: 10 Mei 2019)
}

\begin{abstract}
ABSTRAK
Perilaku mematuk bulu umum ditemukan dalam sutu peternakan yang dipeliahara dengan sistem koloni. Perilaku ini menurunkan efisiensi produksi serta menjadi masalah serius bagi kesejahteraan hewan (Animal welfare). Perilaku mematuk bulu juga dapat memicu terjadinya kanibalisme yang menyebabkan kematian bagi ternak ayam yang menjadi korban. Makalah ini ditulis dengan tujuan mengkaji penyebab terjadinya perilaku mematuk bulu pada peternakan ayam, serta mencari bagaimana upaya yang dapat dilakukan untuk menekan/menghilangkan terjadinya perilaku mematuk bulu pada peternakan ayam yang dipelihara secara sistem koloni. Metode penulisan makalah dilakukan dengan beberapa tahapan. Tahap persiapan, dilakukan dengan mengumpulkan dan membaca jurnal, makalah prosiding, buku yang diperoleh dari hasil dari pencarian pada internet. Tahap penyusunan outline makalah yang akan ditulis. Tahap pengembangan kerangka makalah dengan menggunakan literatur ilmiah, yang diperoleh. Tahap pemeriksaan terhadap isi makalah yang sudah ditulis. Berdasarkan studi pustaka yang dilakukan disimpulkan bahwa berdasarkan faktor penyebabnya, perilaku mematuk bulu disebabkan oleh faktor internal (genetik) dan eksternal (pakan dan lingkungan). Beberapa upaya yang dapat dilakukan untuk mencegah munculnya perilaku mematuk bulu dalam suatu peternakan ayam adalah melalui upaya perbaikan genetik, pemotongan paruh, melalui pendekatan manajemen pakan, serta melaui pendekatan manajemen perkandangan dan lingkungan.
\end{abstract}

Kata kunci: kanibalisme, perilaku mematuk bulu, peternakan ayam

\section{ABSTRACT}

Feather pecking behavior is commonly found in the chicken farms which are reared by the colony system. This behavior reduces production efficiency as well become a serious problem for animal welfare. Feather pecking behavior can also lead to cannibalism which causes death for victim's chicken. This paper was written with the aim of studying the causes of feather pecking behavior in chicken, and looking for ways that can be done to decrease the occurrence of feather pecking behavior on chicken farms. The method of writing a paper was conducted in several stages. The first stage, the preparation, was conducted by searching and reading journals, proceedings, books obtained from the results of searching on the internet. The second stage was the preparation of the outline of the paper to be written. The third stage was developing a framework of thought by using scientific literature obtained and read before. The last stage was by examination of the contents of papers that have been written. Based on the literature study, it was concluded feather pecking behavior is caused by internal (genetic) and external (feed, environmental) factors. Some efforts that can be done to prevent the appearance of feather pecking in chicken farming are through improving genetics, beak trimming, a feed management approach, and through the housing and environmental management approaches.

Keywords: cannibalism, chicken farming, feather pecking 


\section{PENDAHULUAN}

Salah satu permasalahan yang sering ditemukan dalam peternakan ayam yang dipelihara secara sistem koloni (berkelompok) adalah terjadinya perilaku mematuk bulu (Feather pecking), yaitu perilaku dimana suatu ayam mematuk bulu ayam lainnya. Perilaku mematuk bulu terbagi ke dalam dua jenis, yaitu yang dilakukan secara halus dan agresif. Perilaku mematuk bulu secara halus sering dianggap sebagai perilaku mematuk bulu ternak ayam lainnya tanpa sampai membuat tercerabutnya bulu dari ternak ayam yang jadi korban. Sementara itu, perilaku mematuki bulu secara agresif merupakan perilaku mematuk bulu yang mengakibatkan tercerabutnya bulu ternak ayam yang jadi korban, serta mengundang reaksi dari ternak ayam yang jadi korban untuk kemudian menjauh, atau menyerang balik (Keeling, 1994). Lebih detail, Nicol et al. (1999) mengklasifikasikan perilaku mematuk pada ternak unggas menjadi beberapa jenis, pertama, perilaku mematuk agresif (Aggressive pecks), yaitu perilaku mematuk yang diarahkan ke kepala ternak unggas lain dengan posisi postur tubuh mengancam, dengan reaksi penghindaran dari ternak unggas yang menjadi korban. Kedua, perilaku mematuk bulu ringan (Mild feather pecks), yaitu perilaku mematuk bulu yang diarahkan ke bagian bulu mana saja dari ternak unggas korban, dengan pola perilaku mematuk bulu tanpa menjepit, atau hanya menarik sedikit bulu dari ternak korban. Ketiga, perilaku mematuk bulu yang parah (Severe feather pecks), yaitu perilaku mematuk bulu ke bagian mana saja dari bulu ternak unggas yang jadi korban, melibatkan menarik bulu sampai terjadi penarikan bulu yang membuat bulu terlepas. Keempat adalah jenis perilaku mematuk kloaka (Vent pecks), yaitu perilaku mematuk yang diarahkan pada bagian kloaka ternak unggas korban.

Perilaku mematuk bulu pada ayam adalah masalah yang serius bagi kesejahteraan hewan (Animal welfare), sehubungan perilaku ini tidak hanya mengarah pada kerusakan atau tercerabutnya bulu, tetapi juga dapat menyebabkan cedera/rasa sakit, dan bahkan kematian pada ternak ayam yang menjadi korban perilaku tersebut (Hughes dan Duncan, 1972). Perilaku mematuk bulu dapat terjadi pada jenis breed dan galur unggas apapun, serta terjadi pada umur unggas berapa pun (Savory dan Mann, 1999). Kjaer dan Bessei (2013) menjelaskan bahwa perilaku mematuk bulu menjadi masalah serius pada industri ternak unggas, karena perilaku ini, selain menyebabkan ternak unggas menjadi cedera, kesakitan, bahkan kematian. Laporan HuberEicher dan Sebo (2001) menemukan kejadian perilaku mematuk bulu banyak terjadi pada peternakan ayam, terutama ayam petelur. Hasil pengamatannya ditemukan $77 \%$ ternak ayam petelur mengalami perilaku mematuk bulu, yang ditandai dengan adanya kerusakan bulu.

Dampak negatif perilaku mematuk bulu lainnya adalah, perilaku mematuk bulu yang menyebabkan ayam korban menjadi kehilangan bulunya, akan membutuhkan energi lebih besar dalam mempertahankan suhu tubuhnya, akibat hilangnya bulu yang berfungsi sebagai pelindung tubuh dari suhu rendah lingkungan. Kebutuhan energi dari proses metabolisme nutrien untuk mempertahan suhu tubuh tersebut kemudian akan menjadi lebih tinggi. Akibatnya, asupan nutrient yang berasal dari pakan yang dikonsumsi, selanjutnya akan digunakan untuk memenuhi kebutuhan maintenaince yang lebih besar dibandingkan ketika ternak unggas tersebut memiliki bulu yang baik (tidak tercerabut). Dampak penggunaan energi yang lebih besar untuk memenuhi kebutuhan maintenaince yang lebih tinggi, adalah berkurangnya suplay energi untuk memenuhi kebutuhan untuk produksi daging/ telur. Kerugian ekonomi yang disebabkan oleh perilaku mematuk bulu dapat merusak pemeliharaan suhu tubuh, yang mengarah ke peningkatan asupan pakan (Leeson dan Morrison, 1978), yang bisa lebih dari $27 \%$ dari asupan biasa. Pada industri perunggasan yang umumnya memiliki prinsip untuk 
memperoleh efisiensi produksi yang tinggi, maka perilaku mematuk bulu akan dianggap sebagai salah satu sumber dari penyebab kurang efesiennya produksi. Pada tahap selanjutnya, dampak negatif dari perilaku mematuk bulu, adalah dapat menyebabkan terjadinya perilaku kanibalisme, akibat dari perilaku mematuk yang terus menerus dari daerah yang sebelumnya terluka. Koondisi tersebut menyebabkan rasa sakit dan stres pada ayam yang jadi korban, dimana apabila tidak dikendalikan, selanjutnya kemudian dapat menyebabkan kematian.

Berdasarkan penyebabnya, perilaku mematuk bulu dan kanibalisme umumnya dipertimbangkan diakibatkan oleh faktor genetik (internal) dan lingkungan (eksternal) (Kjaer and Bessei, 2013). Berdasarkan pengalaman di lapangan, dimana sering ditemukannya permasalahan berupa perilaku mematuk bulu pada peternakan ayam yang dipelihara secara koloni, telah mengundang penulis untuk mengkaji lebih dalam terkait fenomena perilaku mematuk bulu pada peternakan ayam, dengan harapan dapat membantu peternak dalam menekan/ menghilangkan terjadinya perilaku mematuk bulu pada peternakan ayam mereka. Atas dasar tersebut, maka makalah ini ditulis dengan tujuan untuk mengkaji penyebab terjadinya perilaku mematuk bulu pada peternakan ayam, serta mencari bagaimana upaya yang dapat dilakukan untuk menekan/ menghilangkan terjadinya perilaku mematuk bulu pada peternakan ayam yang dipelihara secara sistem koloni.

\section{METODE}

\section{Sumber Literatur}

Literatur yang digunakan dalam makalah ini merupakan makalah yang diperoleh dari hasil pencarian menggunakan mesin pencarian karya ilmiah: "Google Scholar" dengan menggunakan kata kunci "feather pecking" dan "poultry". Kriteria pemilihan sumber pustaka adalah berasal dari hasil penelitian atau teori dasar yang sudah dipublikasikan dalam bentuk jurnal, makalah prosiding dan buku.

\section{Prosedur Penyusunan Makalah}

Proses penyusunan makalah dilakukan dengan beberapa tahapan. Tahapan pertama, tahap persiapan, dilakukan dengan mengumpulkan dan membaca jurnal, makalah prosiding, buku yang diperoleh dari hasil pencarian. Dilanjutkan dengan memilih dan menentukan jurnal hasil penelitian, makalah ilmiah pada prosiding, buku terkait dengan topik yang sudah ditentukan, yaitu sesuai dengan judul makalah yang akan dibuat "Upaya menekan perilaku mematuk bulu yang memicu perilaku kanibalisme pada peternakan ayam". Tahapan ke dua, penyusunan outline makalah yang akan ditulis, dimana pada tahapan ini untuk menentukan skema berfikir penulis terkait dengan topik yang akan di bahas. Tahapan ke tiga, mengembangkan kerangka pemikiran dalam penyusunan makalah dengan menggunakan informasi ilmiah, teori, hasil penelitian yang diperoleh dari pustaka yang sudah di peroleh sebelumnya untuk kemudian dibuat menjadi sebuat makalah ilmiah. Tahapan ke empat, pemeriksaan terhadap isi makalah yang sudah ditulis, baik secara substansi maupun redaksional.

\section{HASIL DAN PEMBAHASAN}

\section{Penyebab terjadinya perilaku mematuk bulu pada ternak ayam}

Perilaku mematuk bulu pada ternak ayam disebabkan oleh beberapa faktor, yaitu genetika (Kuo et al., 1991), nutrisi/pakan (Green et al., 2000), manajemen kandang (El-Lethey et al., 2001), serta lingkungan (Kjaer and Vestergaard, 1999). Sementara itu, pandangan lain menyebutkan bahwa perilaku mematuk bulu merupakan hasil pengalihan dari perilaku lain, khususnya perilaku mencari makan, di mana ternak unggas memiliki perilaku alamiah untuk mematuk benda lain, guna memuaskan dorongan dalam dirinya 
(Blokhuis 1986).

Beberapa hasil studi menunjukkan bahwa perilaku mematuk bulu pada ternak unggas diakibatkan oleh faktor genetik. Kajian yang menyatakan bahwa penyebab terjadinya perilaku mematuk bulu diakibatkan oleh faktor genetik dikemukakan oleh beberapa peneliti (Flisikowski et al., 2008; Craig and Lee, 1990). Secara genetik, perilaku mematuk bulu dikaitkan dengan rasa ketakutan yang ada dalam diri ternak ayam tersebut. Laporan studi Buitenhuis et al. (2005) menemukan Quantitative Trait Locus (QTL) atau lokus sifat kuantitatif untuk kriteria ketakutan dan mematuk bulu pada kromosom yang sama (GGA1). Albentosa et al. (2003) menemukan secara nyata rasa takut yang jauh lebih tinggi pada strains ayam petelur jenis White Leghorn yang diseleksi berdasarkan perilaku mematuk bulu tinggi dan rendah, dibandingkan dengan tiga strain ayam petelur lainnya (ISA Brown, Blacktail Kolombia dan Ixworth).

Hasil studi juga mengaitkan bahwa perilaku mematuk bulu pada ternak unggas diakibatkan oleh faktor pakan. Beberapa analisa mengungkapkan bahwa perilaku mematuk bulu merupakan peralihan dari perilaku mencari makanan pada ternak ayam, sehingga ketika tidak dijumpai makanan disekitarnya, perilaku tersebut dialihkan ke perilaku mematuk bulu terhadap ternak ayam lainnya. Pakan merupakan aspek penting dari produksi unggas, serta dilaporkan menjadi faktor yang dapat mempengaruhi perilaku ternak unggas. Hal ini terkait dengan status gizi ternak tersebut, dimana status gizi telah terbukti berdampak pada perilaku. Hirsch (1982) menjelaskan bahwa secara sederhana, ternak yang lapar menunjukkan perilaku yang berbeda dari ternak yang kenyang. Lebih jauh lagi, hasil studi Van Krimpen et al. (2005) dan Elwinger et al. (2002) menunjukkan bahwa kandungan gizi protein, asam amino, mineral, energi, dan serat mempengaruhi ada tidaknya perilaku mematuk bulu pada ternak unggas. Selain itu, bentuk pakan, keseimbangan nutrien dalam pakan, kekurangan atau kelebihan makan, pola waktu pemberian pakan, juga dilaporkan mempengaruhi terjadinya perilaku mematuk bulu (Aerni et al., 2000; Green et al., 2000).

Faktor lainnya yang menjadi penyebab munculnya perilaku mematuk bulu adalah faktor manajemen. Manajemen kandang diketahui mempengaruhi terjadinya perilaku mematuk bulu pada ternak ayam. Beberapa studi menunjukkan bahwa kepadatan kandang, ukuran kandang, penempatan sarana pendukung kandang, seperti tempat pakan dan minum, intensitas pencahayaan, dilaporkan mempengaruhi terhadap terjadi tidaknya perilaku mematuk bulu dalam suatu peternakan ayam (Bestman et al., 2009; Deep, 2010).

Pendekatan teori lainnya mencoba menganalisa penyebab terjadinya perilaku mematuk bulu adalah sebagai perilaku yang terkait dengan perilaku alamiah mandi debu yang terdapat pada ternak ayam. Dimana ditemukan bahwa ternak ayam yang dipelihara pada jenis kandang dengan lantai yang tidak mendukung untuk melakukan aktivitas mandi debu tersebut, menunjukkan perilaku mematuk bulu lebih tingggi (Vestergaard dan Lisborg, 1993). Analisa berikutnya mengungkapkan bahwa perilaku mematuk bulu sebagai pengalihan dari perilaku mematuk tanah atau sumber serat yang biasa ternak ayam lakukan ketika dipelihara di alam bebas/ lapangan terbuka. Huber-Eicher and Wechsler (1997) melaporkan bahwa ternak ayam yang diberi ruang untuk memperoleh bahan sumber serat seperti jerami menunjukkan perilaku mematuk bulu yang lebih rendah.

Peneliti lainnya menganalisa bahwa perilaku mematuk bulu juga terkait dengan aspek hormonal yang diturunkan dari ternak induk melalui telur. Von Engelhardt and Groothuis (2011) mengatakan bahwa kuning telur ayam merupakan sumber nutrisi utama untuk embrio yang sedang berkembang di dalam telur, serta mengandung jumlah hormon steroid, seperti estrogen dan androgen. Hormon steroid ini memiliki efek yang lama pada otak dan mempengaruhi perilaku individu ayam. Groothuis et al. (2005) menjelaskan 
bahwa diperlukan studi untuk menyelidiki hubungan antara stress pada ayam indukan, keseimbangan/kandungan hormon telur yang dihasilkan, serta perkembangan perilaku anakanak ayam yang mereka lahirkan kedepannya. Sehingga, jika hubungan seperti itu dapat diketahui, maka keseimbangan hormonal sel telur dapat dijadikan alat untuk memprediksi yang memungkinkan, untuk dapat mengetahui sejak dini perilaku mematuk bulu anak ayam di kemudian hari. Perilaku mematuk bulu juga dilaporkan berkorelasi positif dengan konsentrasi hormon kortikosteron plasma (Vestergaard et al., 1997). Dimana dilaporkan bahwa hormon kortikosteron secara signifikan meningkatkan tingkat perilaku mematuk bulu pada ayam betina (El-lethey et al., 2001).

Sementara itu, pada kajian lainnya, hasil studi mengungkapkan juga, bahwa perilaku mematuk bulu identik terjadi pada ternak ayam yang mudah mengalami kepanikan serta ketakutan. Dimana perilaku mematuk bulu tersebut, dianalisa sebagai ekspressi dari terjadinya stress pada ayam tersebut (Mills dan Faure, 1990). Dengan begitu, maka kemampuan individu ternak ayam dalam menekan tingkat kepanikan/ rasa takut dirinya, menjadi sarana untuk melihat seberapa besar kepemilikan perilaku mematuk bulu pada ternak ayam tersebut. Jones et al. (1995) melaporkan bahwa ternak ayam dari kelompok yang memiliki perilaku mematuk bulu tinggi, lebih menunjukkan rasa takut ketika di tes kepanikan pada lapangan terbuka, daripada ternak ayam dari kelompok dengan perilaku mematuk bulu rendah.

\section{Upaya-upaya dalam menekan perilaku mematuk bulu pada peternakan ayam}

Terdapat beberapa upaya yang dapat dilakukan untuk menekan terjadinya perilaku mematuk bulu pada suatu peternakan ayam, yaitu melalui pendekatan perbaikan genetik, pemotongan paruh, manajemen pakan, serta manajemen perkandangan dan lingkungan.

\section{Perbaikan genetik}

Craig and Lee (1990) mengatakan bahwa perilaku mematuk bulu berkaitan dengan faktor genetika, dimana dilaporkan bahwa jumlah ayam tanpa kerusakan bulu akibat perilaku mematuk bulu mengalami peningkatan pada ayam generasi ke dua setelah dilakukan seleksi terhadap perilaku mematuk bulu. Laporan Flisikowski et al. (2008) mempertegas bahwa perilaku mematuk bulu telah terbukti berhubungan dengan variasi pada gen DRD4 dan DEAF1, meskipun tidak menampik kemungkinan adanya gen lain yang juga ikut terlibat. Setelah teridentifikasinya gen-gen yang mengontrol perilaku mematuk bulu pada ternak ayam, maka dalam pengembangan penelitian ke depan dapat dikembangkan penelitian pemuliaan untuk memperoleh ternak ayam yang tidak memiliki perilaku mematuk bulu, selain melalui pendekatan proses seleksi, juga dapat dilakukan dengan kegiatan pemuliaan berbasis genetika molekuler, untuk menghasilkan breed ayam yang tidak memiliki perilaku mematuk bulu. $\mathrm{Su}$ et al. (2005) merekomendasikan bahwa seleksi genetik untuk strain dengan perilaku mematuk bulu rendah menjadi strategi untuk menghasilkan jenis breed ternak ayam yang tidak memiliki perilaku mematuk bulu di masa depan.

\section{Pemotongan paruh}

Pemotongan paruh merupakan metode yang palingumum diterapkan dalam mencegah perilaku mematuk bulu dan kanibalisme pada industri perunggasan (Cloutier et al., 2000). Terdapat beberapa metode pemotongan paruh yaitu dengan cara mekanik (menggunakan alat pisau dan gunting sederhana), menggunakan pisau panas, menggunakan arus listrik dan menggunakan inframerah (laser), dimana teknik pemotongan paruh menggunakan pisau panas menjadi metode yang paling umum digunakan selama ini (Petrolli et al., 2017). Hasil studi Marchant-Forde et al., (2008) mengungkapkan bahwa pendekatan pemotongan paruh secara tradisional (mekanik atau menggunakan alat pisau dan gunting sederhana) memberikan rasa sakit yang akut bagi ternak ayam, sehingga dipermasalahkan dari aspek kesejahteraan hewan (Animal 
welfare). Para pegiat kesejahteraan hewan menentang praktik pemotongan paruh karena memiliki dampak memberikan trauma kepada ternak selama dilakukannya proses pemotongan, menimbulkan nyeri akibat kerusakan jaringan, serta menimbulkan cedera pada saraf, dan mengakibatkan kehilangan fungsi normal paruh, yang dibuktikan dengan berkurangnya kemampuan untuk merasakan materi dengan paruh (Pakhira et al., 2016).

Praktik pemotongan paruh sebagai upaya untuk menekan terjadinya perilaku mematuk bulu pada ternak unggas menjadi perdebatan diantara beberapa negara. Uni Eropa tidak melarang praktik pemotongan paruh, meskipun ada tekanan dari Jerman untuk melarang prosedur tersebut, dimana Jerman sendiri sudah melarang praktik tersebut mulai tahun 2017. Saat ini, peternak di Jerman hanya diperbolehkan melakukan pemotongan paruh dengan menggunakan metode infra merah (laser) pada saat ternak unggas berumur satu hari (DOC). Begitupula dengan negara Inggris, hanya memperbolehkan pemotongan paruh dengan menggunakan infra merah (laser) saja, dengan batasan umur maksimum dilakukannya pemotongan paruh pada umur 10 hari, serta tingkat pemotongan tidak melebihi $1 / 3$ bagian paruh yang dipotong (Pakhira et al., 2016). Negara Amerika serikat, Australia, dan Kanada masih memperbolehkan praktik pemotongan paruh, namun harus dilakukan oleh praktisi terlatih, dengan alat terkalibrasi, serta dengan metode yang tidak menimbulkan rasa sakit bagi ternak (BTAG, 2015). Pemotongan paruh dengan teknis pemotongan menggunakan infra merah (laser) banyak direkomendasikan karena tidak menyebabkan luka terbuka, mencegah pertumbuhan kembali paruh, dan menghilangkan ujung paruh secara permanen, serta tidak mengakibatkan ternak ayam menderita stres atau merasa sakit yang berkepanjangan. Jacob (2015) mengatakan bahwa pemotongan paruh pada ternak unggas, hanya boleh digunakan untuk mencegah perilaku mematuk bulu dan kanibalisme, ketika pendekatan praktik manajemen (perbaikan genetik, manajemen cahaya, dan manajemen nutrisi) tidak memadai menghambat terjadinya perilaku tersebut. Hanya personel yang terlatih, serta dipantau secara ketat, yang dapat melakukan teknis pemotongan paruh, ditambah dengan syarat harus menggunakan peralatan dan prosedur yang tepat. Cunningham (1992) menambahkan bahwa, pada ternak ayam petelur, meskipun pemotongan paruh dianggap sebagai prosedur yang menimbulkan stres, namun masih memberikan manfaat, yaitu dapat mengurangi perilaku mematuk bulu dan kanibalisme. Perilaku mematuk bulu dapat mengarah terjadinya kanibalisme, yaitu peningkatan kejadian mematuk telur (Tauson and Svensson, 1980). Araújo et al. (2005) mengevaluasi frekuensi kanibalisme pada ayam petelur yang diberi perlakuan tanpa pemotongan paruh, pemotongan paruh ringan ( $1 / 3$ dari paruh) dan pemotongan paruh tinggi ( $1 / 2$ paruh), menghasilkan terjadinya insiden kanibalisme sebesar $13 \%$, 4\%, dan $0 \%$, untuk setiap masing-masing perlakuan secara berturut turut, dalam periode hingga umur 13 minggu.

\section{Manajemen Pakan}

Suatu studi yang menganalisa bahwa perilaku mematuk bulu merupakan sebagai pengalihan perilaku dari proses perilaku dalam mencari dan mematuk makanan, menjadi dasar bahwa perilaku mematuk bulu dapat dtekan melalui pendekatan manajemen pakan. Asupan nutrisi makanan termasuk protein, energi, asam amino, lemak, dan karbohidrat mempengaruhi perilaku hewan (Bosch et al., 2007). Beberapa hasil studi juga menunjukkan bahwa perilaku mematuk bulu terkait pula dengan telah terjadinya defisiensi nutrisi. Ambrosen and Petersen, (1997) melaporkan bahwa defisiensi protein menyebabkan terjadinya peningkatan perilaku kanibalisme dan mematuk bulu yang ditandai dengan banyaknya kondisi bulu yang rusak atau tercerabut. Perilaku mematuk bulu juga ditemukan ketika terjadi defisiensi asam amino lisin, mineral magnesium, seng dan sodium (Al Bustany dan Elwinger, 1987; Schaible et al., 1947; Sunde, 1972; Hughes and Whitehead, 
1974). Perilaku mematuk bulu dianalisa juga diakibatkan oleh pengalihan perilaku mematuk tanah dan bahan sumber serat. Keberadaan serat dalam saluran pencernaan unggas, bermanfaat pada motilitas usus, serta menimbulkan rasa kenyang. Serat juga akan terakumulasi dalam rempela, sehingga jumlah bagian dari digesta yang melalui rempela menjadi berkurang, sehingga berdampak pada peningkatan rasa kenyang, yang berdampak dalam mengurangi kecenderungan untuk melakukan perilaku mematuk bulu (Hetland et al., 2004; Van Krimpen et al., 2011). Efek yang ditimbulkan oleh serat di atas, hampir sama dengan yang ditimbulkan ketika ternak unggas mengkonsumsi bulu. Hasil studi Harlander-Matauschek et al. (2006) memberikan kesimpulan bahwa ternak ayam mengkonsumsi atau mematuk bulu, dalam rangka untuk meningkatkan rasa kenyang bagi tubuhnya. Atas dasar tersebut, Van Der Lee et al. (2001) memberikan rekomendasi bahwa pengoplosan pakan dengan bahan sumber polisakarida non-pati (NSP) mampu mengurangi terjadinya perilaku mematuk bulu. Pengoplosan pakan dengan bahan sumber polisakarida non-pati (NSP) akan menurunkan kandungan energi metabolis pakan, dampaknya akan menyebabkan peningkatan waktu makan (Savory, 1980). Hal Ini dapat berdampak dalam menurunnya waktu yang dihabiskan untuk melakukan perilaku mematuk bulu. Pada laporan lainnya, Aerni et al. (2000) menemukan bahwa menyediakan bahan sumber serat berupa jerami sebagai substrat untuk dijadikan target mencari makan bagi ternak unggas, dapat membantu mengurangi terjadinya perilaku mematuk bulu dan tingkat ketercerabutan/ kerusakan bulu.

Perilaku mematuk bulu pada ternak ayam juga dikaitkan dengan defisiensi terhadap asam amino triptofan. Asam amino triptofan terkait dengan perilaku agresif ternak, seperti mematuk bulu karena merupakan prekursor dari serotonin (Savory et al., 1999). Serotonin merupakan senyawa pemicu ketenangan dalam tubuh. Bulu terbentuk dari struktur protein, jenis keratin, yang mengandung asam amino seperti triptofan. Ternak unggas yang mengkonsumsi bulu, mungkin melakukan hal tersebut dalam rangka mencari asam amino yang kurang dalam makanan mereka, seperti triptofan, yang dibutuhkan untuk membantu membentuk serotonin, dan meningkatkan level serotonin dalam tubuh, yang dibutuhkan oleh tubuh ternak unggas untuk menciptakan efek menenangkan pada tubuh mereka.

Perilaku mematuk bulu banyak dianalisa oleh para nutrisionis unggas sebagai perilaku untuk "mengisi waktu kosong" dari aktivitas makan bagi ternak unggas. Hartini et al. (2003) melakukan penelitian terkait pengaruh bentuk pakan (pellet vs mash) terhadap perilaku mematuk bulu, dimana dihasilkan bahwa peningkatan perilaku mematuk bulu terjadi pada kelompok ternak ayam yang diberi pakan dalam bentuk pellet. Fenomena ini dikaitkan dengan peningkatan waktu yang dibutuhkan untuk mengkonsumsi makanan dalam bentuk mash (tepung), yang akan membutuhkan waktu lebih lama, sehingga memberikan dampak terhadap akan diperoleh lebih sedikitnya waktu yang tersisa, untuk melakukan aktivitas lain, termasuk perilaku mematuk bulu. Pemberian pakan dalam bentuk mash (tepung) akan diperoleh pakan yang tidak selalu digiling dalam ukuran yang sama, sehingga menyisakan berbagai ukuran dan warna. Variasi tersebut dapat merangsang mematuk dan menyortir pakan untuk dikonsumsi, sehingga membutuhkan waktu yang lebih lama, dibandingkan ketika diberi pakan dalam bentuk pellet. Hal ini sesuai dengan konsep the redirected foraging theory, dimana semakin banyak waktu yang dibutuhkan untuk aktivitas mencari makan, maka akan sedikit waktu yang digunakan untuk melakukan perilaku diluar mencari makan, diantaranya perilaku mematuk bulu (Blokhuis, 1986). Dari uraian diatas dapat direkomendasikan bahwa upaya penekanan perilaku mematuk bulu pada ternak ayam melaui pendekatan manajemen pakan dapat dilakukan dengan mengatur agar ternak ayam dapat lebih banyak menghabiskan waktunya 
untuk melakukan perilaku makan, yaitu dengan melalui beberapa pendekatan, yaitu; diberi pakan dalam bentuk tepung (mash), diberi pakan yang mengandung energi rendah serta mengandung serat tinggi. Disamping itu, memberikan pakan yang menunjang terpenuhinya kandungan nutrisi ternak ayam sebagaimana tingkat kebutuhan gizinya, juga akan menekan timbulnya perilaku mematuk bulu (Van Krimpen et al., 2005).

\section{Manajemen Perkandangan dan Lingkungan}

Upaya penurunan perilaku mematuk bulu dapat dilakukan dengan pendekatan manajemen perkandangan. Tingkat intensitas cahaya dalam kandang mempengaruhi terjadinya perilaku mematuk bulu. Mengatur intensitas pencahayaan yang benar dalam kandang sangat penting dalam membantu mengurangi terjadinya perilaku mematuk bulu (D'Eath et al., 2003). Taylor et al. (2003) mengatakan bahwa intensitas cahaya yang rendah akan menekan keaktifan ternak dalam kandang, sehingga juga dapat menekan terjadinya perilaku mematuk bulu pada ternak ayam dalam kandang tersebut. Kjaer and Vesterguard (1999) menemukan peningkatan intensitas cahaya dari 3 lux hingga 30 lux meningkatkan perilaku mematuk bulu.

Perilaku mematuk bulu dianalisa juga sebagai bentuk peralihan perilaku dari perilaku mandi debu yang tidak tersalurkan karena kondisi perkandangan yang tidak mendukung. Atas dasar tersebut, maka memfasilitasi kandang dengan area yang dapat mendukung ternak ayam melakukan aktiivitas mandi debu, dilaporkan dapat menurunkan perilaku mematuk bulu terhadap ternak ayam lainnya (Blokhuis, 1989). Laporan Aerni et al. (2000) menunjukkan bahwa kondisi bulu ayam yang dipelihara dalam kandang litter menunjukkan kondisi bulu yang lebih baik dibandingkan dengan kondisi bulu ayam yang dipelihara dalam kandang cages, hal ini karena ternak ayam memiliki kesempatan untuk melakukan aktivitas mandi debu di dalam kandang litter. Keberadaan area untuk ternak ayam melakukan aktivitas outdoor yang tersedia tanaman pepohonan menghasilkan rendahnya kejadian perilaku mematuk bulu (Bestman and Wagenaar, 2003). Hasil studi juga menunjukkan bahwa perilaku mematuk bulu memiliki hubungan korelasi negatif dengan perilaku mematuk tanah, sehingga memfasilitasi kandang untuk ternak ayam melakukan aktivitas mematuk tanah menjadi upaya dalam mengalihkan atau menekan perilaku mematuk bulu (Huber-Eicher and Wechsler, 1998). Hal ini mendukung analisa, bahwa perilaku mematuk bulu merupakan peralihan perilaku dari perilaku mematuk tanah yang terdapat pada ternak unggas, termasuk ternak ayam.

Wechsler dan Huber-Eicher (1998) mengatakan bahwa penyediaan tempat bertengger dalam kandang juga dapat menekan terjadinya perilaku mematuk bulu. Selain itu, upaya untuk menekan perilaku mematuk bulu juga dapat dilakukan dengan menaburkan bahan sumber serat, seperti jerami di lantai kandang (Blokhuis and Van der Haar, 1992). Langkah upaya lainnya dalam menekan perilaku mematuk bulu dalam peternakan ayam adalah dengan memasangkan paruh dengan Blinders atau peepers, yaitu alat yang dipasang pada paruh unggas untuk menghalangi pandangan ke depan dan membantu dalam pengendalian pematuk bulu, kanibalisme, dan memakan telur (Jones and Carmichael, 1999). Perilaku mematuk bulu juga dapat ditekan dengan mengatur kepadatan kandang. Savory et al. (1999) melaporkan bahwa perilaku mematuk bulu pada ternak ayam dalam suatu kandang berkaitan dengan tingkat kepadatan kandang. Semakin tinggi tingkat kepadatan, maka perilaku mematuk bulu juga akan semakin tinggi. Penempatan dan penggunaan peralatan seperti kotak sarang dalam kandang, juga dilaporkan dapat mengurangi perilaku mematuk bulu (van Krimpen et al., 2005).

Modifikasi lingkungan melalui perangkat atau benda yang akan memancing perhatian ternak unggas sehingga mengalihkan perhatian dan perilaku mematuk bulunya ke arah benda atau perangkat

Upaya Menekan Perilaku Mematuk ... (Hidayat) 
tersebut, menjadi alah satu upaya dalam menekan perilaku mematuk bulu pada ternak unggas. Sherwin et al. (1999) melaporkan keberhasilannya dalam menekan perilaku mematuk bulu pada ternak kalkun melalui pendekatan modifikasi lingkungan pada kandang, dengan menyediakan berbagai benda seperti rantai dan tali di dalam kandang sebagai sarana untuk mengalihkan perhatian ternak unggas tersebut dari perilaku mematuk bulu. Penyediaan bahan kawat sederhana yang digantung di kandang ternak unggas, juga dilaporkan dapat menurunkan perilaku mematuk bulu pada ternak unggas yang tidak dilakukan pemotongan paruh (McAdie et al., 2005). Jones et al. (2000) melaporkan bahwa kawat berwarna putih lebih disukai ternak ayam daripada warna lain.

\section{KESIMPULAN}

Perilaku mematuk bulu menjadi masalah dalam pemeliharaan ayam pada sistem koloni. Perilaku ini menjadi masalah serius bagi kesejahteraan hewan (Animal welfare), karena akan menyebabkan cedera bahkan memicu terjadinya perilaku kanibalisme yang dapat menyebabkan kematian bagi ternak ayam yang menjadi korban. Penyebab timbulnya perilaku mematuk bulu diakibatkan oleh faktor internal (genetik) dan eksternal (pakan dan lingkungan). Beberapa upaya yang dapat dilakukan untuk mencegah munculnya perilaku mematuk bulu dalam suatu peternakan ayam adalah melalui upaya perbaikan genetik, pemotongan paruh, melalui pendekatan manajemen pakan dan pendekatan manajemen perkandangan serta lingkungan.

\section{DAFTAR PUSTAKA}

Aerni, V., H. El Lethey, and B. Wechsler. 2000. Effect of foraging material and food form on feather pecking in laying hens. British Poultry Science 41 (1): 16-21.
Al Bustany, Z. and K. Elwinger. 1987. Response of laying hens to different dietary lysine intakes. A comparison of some commercial hybrids with strains selected on a low protein diet. Acta Agriculturae Scandinavica 37: 27-40.

Albentosa, M. J., J. B. Kjaer. and C. J. Nicol. 2003. Strain and age differences in behaviour, fear response and pecking tendency in laying hens. Brit. Poult. Sci. 44 : 333-344.

Ambrosen, T. and V. E. Petersen. 1997. The influence of protein level in the diet on cannibalism and quality of plumage of layers. Poultry Science 76: 559-563.

Araújo, L. F., M. B. Café. and N. S. M. Leandro. 2005. Performance of layer hens submitted or not to different methods of the beak trimming. Ciência Rural 35(1):169-173.

Bestman, M. W. P. and J. P. Wagenaar. 2003: Farm level factors associated with feather pecking in organic laying hens. Livst Prod Sci 80: 133-140

Bestman, M., P. Koene, and J. P. Wagenaar. 2009. Influence of farm factors on the occurrence of feather pecking in organic reared hens and their predictability for feather pecking in the laying period. Appl. Anim. Behav. Sci. 121:120-125.

Blokhuis, H. J. 1986. Feather-pecking in poultry: its relation with groundpecking. Appl. Anim. Behav. Sci. 16: 63-67.

Blokhuis, H. J. and J. W. Van Der Haar. 1992. Effects of pecking incentives during rearing on feather pecking of laying hens. British Poultry Science 33: 17-24.

Blokhuis, H. J. 1989. The development and causation of feather pecking in the domestic fowl. - Vakgroep Ethologie, Thesis Landbouw Universiteit Wageningen, Wageningen.

Bosch, B., W. H. Beerda, B., Hendriks., A. F. B. van der Poel. and M.W.A. Verstegen. 2007. Impact of nutrition on canine 
behaviour: current statues and possible mechanisms. Nutr. Res. Rev. 20: 180194.

BTAG. 2015. The Beak Trimming Action Group's review https://www.gov.uk/ government/uploads/system/uploads/ attachment_data/file/480111/BeakTrimming-Action-Group-Review.pdf Accessed 06.04.2019.

Buitenhuis, A. J., T. B. Rodenburg., M. Siwek., S. J. B. Cornelissen., M. G. B. Nieuwland., R. P. M. A. Crooijmans., M. A. M. Groenen., P. Koene., H. Bovenhuis, and J. J. Van Der Poel. 2005: Quantitative trait loci for behavioural traits in chickens. Livest. Prod. Sci. 93, 95-103.

Cloutier, S., R. C. Newberry., C. T. Forster. and K. M. Girsberger. 2000. Does pecking at inanimate stimuli predict cannibalistic behaviour in domestic fowl? Applied Animal Behaviour Science 66 (1-2): 119-133.

Craig, J. V. and H. Y. LEE. 1990. Beak trimming and genetic stock effects on behavior and mortality from cannibalism in white leghorn-type pullets. Applied Animal Behaviour Science, 25: 107-123.

Cunningham, D. L. 1992. Beak trimming effects on performance, behavior and welfare of chickens: a review. Journal Applied Poultry Research 1:129-134.

D'Eath, R. B. and L. J. Keeling. 2003. Social discrimination and aggression by laying hens in large groups: from peck orders to social tolerance. Appl. Anim. Behav. Sci. 84, 197-212.

Deep, A. 2010. Impact of light intensity on broiler live production, processing characteristics, behaviour and welfare. M.Sc. Thesis. University of Saskatchewan, Saskatoon, Canada.

El-Lethey, H., T. W. Jungi, and B. HuberEicher. 2001. Effects of feeding corticosterone and housing conditions on feather pecking in laying hens
(Gallus gallus domesticus). Physiol Behav 73: 243-251

Elwinger, K., R. Tauson., M. Tufvesson, and C. Hartmann. 2002. Feeding of layers kept in an organic feed environment. 11th. European Poultry Conference, Bremen.

Flisikowski, K., H. Schwarzenbacher., M. Wyscoki., S. Weigend., R. Preisinger., J. B. Kjaer, and R. Fries. 2008. Variation in neighbouring genes of the dopaminergic and serotonergic systems affects feather pecking behaviour of laying hens. Anim. Genet. 40: 192-199.

Green, L. E., K. Lewis., A. Kimpton, and C. J. Nicol. 2000. Cross-sectional study of the prevalence of feather pecking in laying hens in alternative systems and its associations with management and disease. Vet Rec 147: 233-238.

Groothuis, T. G. G., W. Muller., N. Von Engelhardt., C. Carere, and C. Eising. 2005. Maternal hormones as a tool to adjust offspring phenotype in avian species. Neuroscience and Biobehavioral Reviews 29: 329-352.

Harlander-Matauschek, A., H. P. Piepho, and W. Bessei. 2006. The effect of feather eating on feed passage in laying hens. Poultry Science 85: 21-25.

Hartini, S., M. Choct., G. Hinch, and J.V. Nolan. 2003. Effect of diet composition, gut microbial status and fibre forms on cannibalism in layers. AECL 03/03, 1-111.

Hetland, H., M. Choct, and B. Svihus. 2004. Role of insoluble non-starch polysaccharides in poultry nutrition. World's Poultry Science Journal 60: 415-422.

Hirsch, J. 1982. The interactions of nutrition and behavior. Am. J. Clin. Nutr. 35: 1200-1201.

Huber-Eicher, B, and B. Wechsler. 1997. Feather pecking in domestic chicks: its relation to dustbathing and foraging. 
Animal Behaviour 54: 757-768.

Huber-Eicher, B, and F. Sebo. 2001.The prevalence of feather pecking and development in commercial flocks of laying hens. Applied Animal Behavior Science 4:223-231.

Huber-Eicher, B. and B. Wechsler. 1998. The effect of quality and availability of foraging materials on feather pecking in laying hen chicks. Anim. Behav. 55, 861-873.

Hughes, B. O. and I. J. H. Duncan. 1972. The influence of strain and environmental factors upon feather pecking and cannibalism in fowls. British Poultry Science 13: 525-547.

Hughes, B. O. and C. C. Whitehead. 1974. Sodium deprivation, feather pecking and activity in laying hens. British Poultry Science 15: 435-439.

Jacob, J. 2015. Beak Trimming of Poultry in Small and Backyard Poultry Flocks. University of Kentucky [internet]. https://articles.extension. org/pages/66245/beak-trimmingof-poultry-in-small-and-backyardpoultry-flocks. Cited march 312019.

Jones, B. R. and N. L. Carmichael. 1999. Responses of domestic chicks to selected pecking devices presented for varying durations. Appl Anim Behav Sci 64: 125-140.

Jones, R. B., H.J. Blokhuis. and G. Beuving. 1995. Open-field and tonic immobility responses in domestic chicks of two genetic lines differing in their propensity to feather peck. British Poultry Science 36: 525-530.

Jones, R. B., N. L. Carmichael, and E. Rayner. 2000. Pecking preferences and pre-dispositions in domestic chicks: implications for the development of environmental enrichment devices. Applied Animal Behaviour Science, 69: 291-312.

Keeling, L. J. 1994. Feather pecking - who in the group does it, how often and under what circumstances? Proceedings of the 9th European Poultry Conference, Glasgow. 288-289.

Kjaer, J. and W. Bessei. 2013. The interrelationships of nutrition and feather pecking in the domestic fowl-A review. Archiv Für Geflügelkunde. 77, $1-9$.

Kjaer, J. B. and K. S. Vestergaard. 1999. Development of feather pecking in relation to light intensity. Appl. Anim. Behav. Sci. 62: 243-254.

Kuo, F. L., J. V. Craig, and W. M. Muir. 1991. Selection and beak trimming effects on behavior, cannibalism, and short term production traits in White Leghorn pullets. Poultry Science 70:1057-1068.

Leeson, S. and W. D. Morrison. 1978. Effect of feather cover on feed efficiency in laying birds. Poultry Science. 57:10941096.

Marchant-Forde, R. M., A. G. Fahey, and H. W. Cheng. 2008.Comparative effects of infrared and one-third hot-blade trimming on beak topography, behavior, and growth. International Journal of Poultry Science 87:1474-1483

McAdie, T. M., L. J. Keeling., H. J. Blokhuis, and R. B. Jones. 2005. Reduction in feather pecking and improvement of feather condition with the presentation of a string device to chickens. Applied Animal Behaviour Science, 93: 67-80.

Mills, A. D, and J. M. Faure. 1990. Panic and hysteria in domestic fowl: a review. In: Zayan, R. and R. Dantzer (Eds); 1990; Social Stress in Domestic Animals, Dordrecht, Kluwer Academic, 248-72.

Nicol, C. J., N. G. Gregory., T. G. Knowles., I. D. Parkman, and L. J. Wilkins. 1999. Differential effects of increase stocking density, mediated by increased flock size, on feather pecking and aggression in laying hens. Appl Anim Behav Sci 65: 137-52. 
Pakhira, M. C., P. Biswas., D. C. Roy., M. Roy, S. Bera., P. S. Jana, and A. K. Das. 2016. Controlling Feather Pecking \& Cannibalism in Laying Hens without Beak Trimming in Deep Litter- A Review. Advances in Life Sciences 5 (10) : 3904-3911.

Petrolli, T. G., O. J. Petrolli., L. K. Girardini., M. L. A. N. Zotti., R. A. Baggio, and O. M. Junqueira. 2017. Effects of Laser Beak Trimming on the Development of Brown Layer Pullets. Brazilian Journal of Poultry Science 19 (1) : 123-128

Savory, C. J., J. S. Mann, and M. G. Macleod. 1999: Incidence of pecking damage in growing bantams in relation to food form, group size, stocking density, dietary tryptophan concentration and dietary protein source. Br Poult Sci 40: 579-584.

Savory, C. J. 1980. Meal occurrence in Japanese quail in relation to particle size and nutrient density. Animal Behaviour 28: 160-171.

Schaible, P. J., J. A. Davidson, and S. L. Bandemer. 1947. Cannibalism and feather pecking in chicks as influenced by certain changes in a specific ration. Poultry Science 26: 651-656.

Sherwin, C. M., P. D. Lewis, and G. C. Perry. 1999. The effects of environmental enrichment and intermittent lighting on the behaviour and welfare of male domestic turkeys. Appl. Anim. Behav. Sci. 62 (4), 319-333.

Su, G., J. B. Kjaer, and P. Sorensen. 2005. Variance components and selection response for featherpecking behavior in laying hens. Poult. Sci. 84, 14-21.

Sunde, M. L. 1972. Zinc requirement for normal feathering of commercial Leghorn-type pullets. Poultry Science 51: 1316-1322.

Tauson, R, and S. A. Svensson. 1980. Influence of plumage condition on the hen's feed requirement. Swedish Journal Agricultural Research 10:35-39.
Taylor, P. E., G. B. Scott, and P. Rose. 2003: The ability of domestic hens to jump between horizontal perches: effect of light intensity and perch colour. Appl Anim Behav Sci 83: 99-108.

Van Der Lee, A. G., G. Hemke, and R. P. Kwakkel. 2001. Low density diets improve plumage condition in nondebeaked layers. Proceedings of the 13th European Symposium on Poultry Nutrition, Blankenbergen, Belgium, pp. 244-245.

Van Krimpen, M. M., R. P. Kwakkel., B. F. J. Reuvekamp., C. M. C. Van Der Peet-Schwering., L. A. Den Hartog, and M. W. A. Verstegen. 2005. Impact of feeding management on feather pecking in laying hens. World's Poultry Science Journal 61: 663-685.

Van Krimpen, M. M., R. P. Kwakkel., C. M. C. Van Der Peet-Schwering., L. A. Den Hartog, and M. W. A. Verstegen. 2011. Effects of dietary energy concentration, nonstarch polysaccharide concentration, and particle sizes of nonstarch polysaccharides on digesta mean retention time and gut development in laying hens. British Poultry Science 52: 730-741.

Vestergaard, K. S, and L. Lisborg. 1993. A model of feather pecking development which relates to dustbathing in the fowl. Behaviour 126: 291-308.

Vestergaard, K. S., E. Skadhauge, and L. G. Lawson. 1997: The stress of not being able to perform dustbathing in laying hens. Physiol Behav 62: 413-419.

Von Engelhardt, N. and T. G. G. Groothuis. 2011. Maternal hormones in avian eggs, in: Norris, D. O. and Lopez, K. H. (Eds) Hormones and Reproduction of Vertebrates, Volume 4: Birds, pp. 91127 (Academic Press).

Wechsler, B, and B. Huber-Eicher. 1998. The effect of foraging material and perch height on feather pecking and feather damage in laying hens. Appl Anim

Upaya Menekan Perilaku Mematuk ... (Hidayat) 
Vol. 21 (2): 163-175

Behav Sci 58: 131-141. 